\title{
Immunological techniques in diabetes research: 14 years on
}

\author{
C. N. Hales \\ Department of Clinical Biochemistry, University of Cambridge, Addenbrooke's Hospital, Cambridge, UK
}

The sixth Minkowski Award Lecture described a number of novel immunological techniques which it was thought might find an application in diabetes research [1]. The methods exploited solid-phase procedures used either in an analytical or preparative fashion. The methods have been applied in diabetes research in my laboratory in attempts to define the role of insulin deficiency in the syndrome, to purify plasma membranes and to study the control of insulin secretion.

\section{Measurement of plasma insulin and proinsulin in diabetes}

The description of the glucose fatty-acid cycle in the early 1960s [2] raised the possibility that the increased lipid mobilisation observed in diabetes could be a primary cause of insulin resistance with the possibility of later secondary failure of insulin production [3, 4]. Alternatively, a primary deficiency of insulin could lead to excessive lipid mobilisation, insulin resistance and eventual ketoacidosis. Our initial use of insulin radioimmunoassay was therefore directed at the earliest manifestations of diabetes in an attempt to define the availability of plasma insulin before the onset of glucose tolerance. It was observed that metabolic abnormalities suggestive of insulin resistence were present in an individual 4 years before the sudden onset of diabetic ketoacidosis [5]. The existence of a fairly long prodromal period before the onset of Type 1 (insulin-dependent) diabetes is now beginning to be accepted, although whether an early phase of insulin resistence occurs is still not clear (see below). A prospective study of adults showed that defective insulin production could be detected before an elevation of the fasting glucose concentration. This indicated that the well-recognised slow insulin response to oral glucose in adult diabetic patients was not solely due to chronic overstimulation consequent upon an elevated fasting glucose concentra- tion. Greatly reduced insulin production appeared to be a major aetiological factor in the production of diabetes in this group [6]. As a further test of the possibility that chronic overstimulation leading to a depletion of stored insulin could be responsible for a delay in insulin secretion, the effects of a period of pharmacological blockade of insulin release were investigated. Drawing upon information derived from studies of inhibitors of insulin secretion in vitro [7], diazoxide was selected for use as a "broad spectrum" inhibitor which did not inhibit insulin synthesis. It was found that after 1 week's inhibition of insulin secretion by diazoxide the acute insulin response to a major intravenous stimulus was dramatically increased. The concentrations of insulin achieved in plasma approached those of normal subjects given a similar stimulus [8]. Thus, deficient insulin stores could be an important factor in determining acute insulin responses. However, the observed time lag with which these higher insulin concentrations were reached suggested an abnormality of the release process additional to that due to decreased insulin stores.

In the 1971 Minkowski Lecture I outlined the principle and reported the use of the two-site immunoradiometric assay. In this procedure an antibody against one epitope of an antigen is bound to a solid phase and an antibody to a second epitope is labelled with ${ }^{125} \mathrm{I}$. In order to label an antibody to high specific activity, we used methods we had devised previously for the single site immunoradiometric assay and which produced small amounts of very pure antibody $[9,10]$. At that time we had successfully used the two-site method in the assay of human growth hormone [11]. I pointed out that in theory the method should be suitable for the specific measurements of proinsulin in plasma even in the presence of insulin and C-peptide. However, in practice the direct application of the method to proinsulin was hampered by the extreme shortage of antisera to C-peptide and of C-peptide itself rendering the isolation and iodi- 

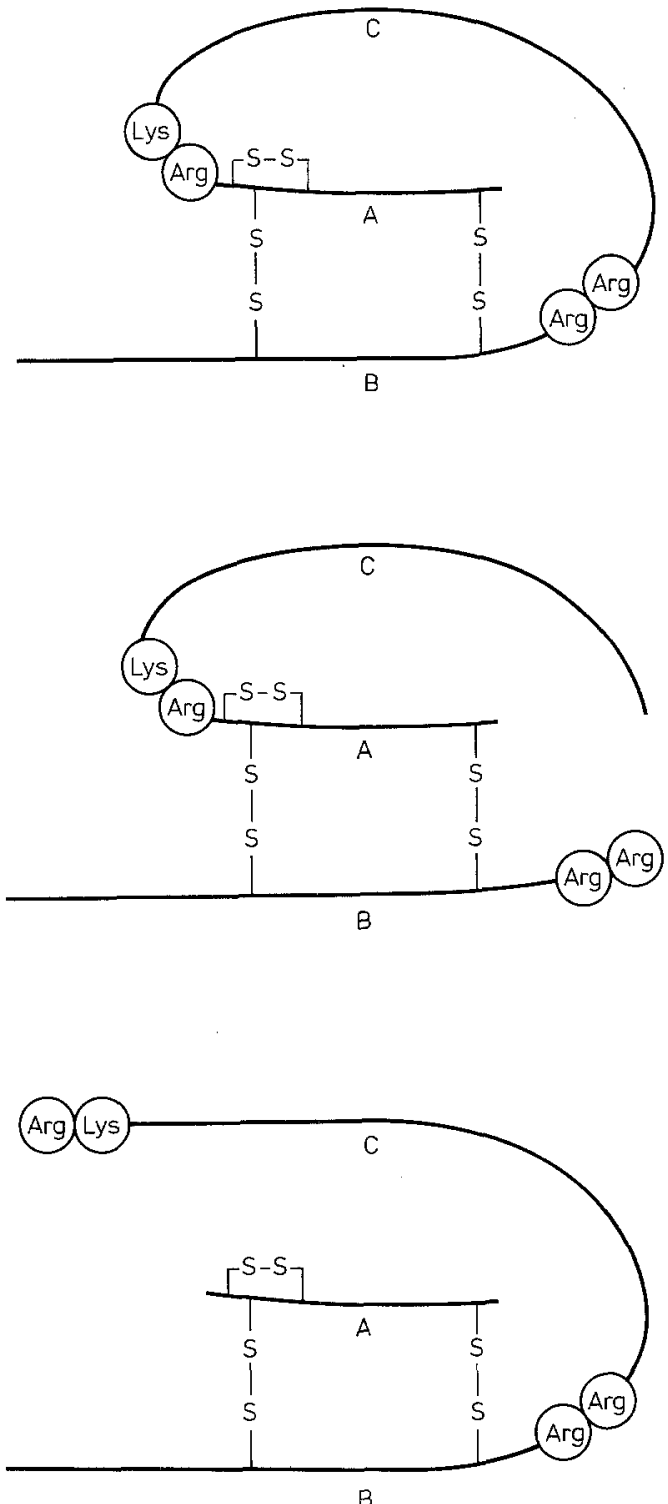

Fig. 1. Diagram of human proinsulin (top) and the initial products of proteolytic processing, $32 / 33$ split in the middle and $65 / \mathrm{A} 1$ split at the bottom

nation of antibodies impossible. To overcome this problem, P. Beck and I devised and established a method which we termed an indirect two-site immunoradiometric assay [12]. This method involved the preparation, purification and iodination of anti-(immunoglobulin) antibodies. As soon as we were given antibodies to human C-peptide, we were able to establish an assay for human proinsulin using this procedure [13] (Fig. 1). The assay had the virtue of being readily applicable to the assay of proinsulin from most species provided an antiserum to the relevant C-peptide was available [14]. Like all other proinsulin assays available at that time, it could not, at least in theory, distinguish between intact and partially processed proinsulin (Fig. 2). Since there was obviously

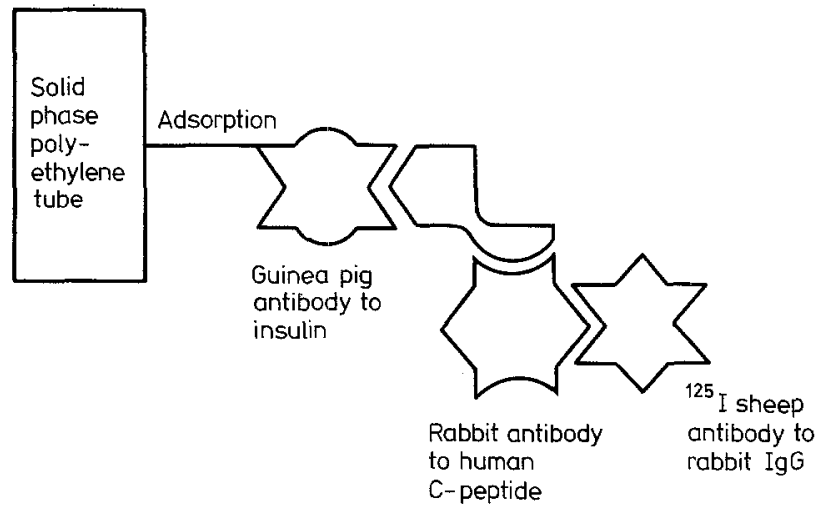

Fig. 2. Principle of the indirect immunoradiometric assay of human proinsulin. The assay measures $32 / 33$ and $65 / \mathrm{A} 1$ split proinsulin ( 3 ) equally well but not intact proinsulin

no realistic prospect of examining this aspect of the problem, apart from pointing it out, we had otherwise to ignore it. We subsequently described a micro-version of the assay, conveniently carried out in disposable pipette tips [15].

The use of the proinsulin assay in diabetes confirmed what had been observed by others, namely that the amount of proinsulin present in fasting plasma was considerably elevated in many patients. It also became clear from this and other work that because of the fairly high cross-reactivity of proinsulin in most insulin radioimmunoassays, a very significant amount of what had been thought of as "insulin" in the plasma of diabetic patients could well be biologically inactive proinsulin. Thus, conclusions concerning the insulin sensitivity of diabetic subjects, which were based upon the observation of "normal" or "elevated" plasma insulin concentrations, had to be reassessed. In preliminary studies, we looked for an explanation of the elevated proinsulin levels in diabetes. A simple possibility was that chronically elevated plasma glucose concentrations continually depleted stores of plasma insulin (for which as I have mentioned we had some evidence) and hence newly synthesised insulin was packaged and secreted before there was adequate time for complete conversion of proinsulin to insulin. The diabetic could then be envisaged as suffering "double jepardy", not only was he or she producing too little insulin but in addition, and because of this, a significant portion of what was produced was liberated ineffectually as biologically inactive proinsulin. If inadequate time for processing was the basis of the high plasma proinsulin concentration, then the reduction of the rate of insulin release by a drug, such as diazoxide, should reverse the situation. Our data thus far are consistent with the overstimulation concept [16].

The growing realisation of the importance of autoimmunity in Type 1 diabetes has raised interesting questions in relation to the use and interpretation of assays 


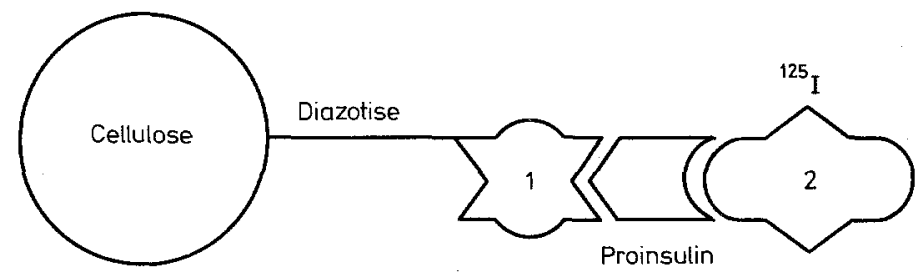

Fig. 3. Principle of the monoclonal two-site immunoradiometric assay of human proinsulin. A mouse monoclonal antibody [1] which cross-reacted with both insulin and proinsulin was coupled to finely divided cellulose by diazotisation. The second mouse monoclonal antibody [2] is one which did not react with either insulin or free C-peptide, but reacted fully with intact proinsulin, $50 \%$ with $65 / \mathrm{Al}$ split proinsulin and not at all with $32 / 33$ split proinsulin (I. P. Gray, K. Siddle, B.H. Frank, C. N. Hales, unpublished observations)

Table 1. Some applications of the immunoradiometric assay

$\alpha$-Fetoprotein

Carcinoembryonic antigen

Prostatic acid phosphatase

Placental alkaline phosphatase

Complement component C9

Ferritin

Interferon

Myoglobin

Chorionic gonadotropin

Luteinising hormone

Thyroid stimulating hormone

Growth hormone

Prolactin

Parathyroid hormone

Proinsulin

Sex hormone binding globulin

$\beta$-Thromboglobulin

References to most of these assays may be found in [22]

of insulin and proinsulin in this condition. My colleagues, A.K. Campbell and J.P. Luzio, discovered that the earliest detectable event in complement-mediated red cell lysis was an increase in intracellular $\mathrm{Ca}^{2+}[17]$. Aware of the key role that calcium plays in the mediation of many intracellular regulatory processes, they suggested that complement-mediated immune attack, which fell short of causing cell death, might nevertheless cause important aberrations of cell regulation [18]. In the context of diabetes and insulin secretion, one might expect such an immune attack to increase insulin secretion. It thus becomes of great interest to define the pattern of insulin secretion in the pre-diabetic phase of Type 1 diabetes. Possible hypersecretion of insulin and/ or proinsulin could be responsible for the apparent insulin resistence which we observed 4 years before the onset of ketoacidosis.

At this stage, molecular biological and cell hybridisation techniques provided new tools with which to tackle these difficult problems. The previous extreme shortages of human proinsulin and C-peptide, and an- tisera thereto disappeared due to the biosynthetic production of human proinsulin [19] and the description of the monoclonal antibody technique [20]. We set out to utilise these advances firstly by replacing our crude human pancreatic proinsulin standard with one produced by biosynthesis. It came as something of a shock to discover that biosynthetic human proinsulin was almost completely unreactive in our assay. We were able to show that the assay only recognised partially cleaved proinsulin [21]. The interesting inference of this work was that all the material we had measured as "proinsulin" in plasma was cleaved proinsulin and furthermore since our results agreed so well with those of other workers, the same might be true of all the previous measurements. Very recent work, using an iodinated monoclonal antibody specific for proinsulin in a two-site assay (Fig. 3), suggests that intact proinsulin comprises approximately $25 \%$ of the proinsulin-like material in plasma from normal fasting subjects.

During an oral glucose tolerance test in normal subjects, the proportion of intact proinsulin in plasma falls slightly initially due to a more rapid rise of split proinsulin. Three hours after the start of the test the amount of intact proinsulin has risen to approach the amount of the partially processed intermediates. Thus, the release of intact proinsulin from the $\beta$ cell appears to follow very different kinetics from those of either insulin or the split intermediates. It is possible, therefore, that assays specific for intact proinsulin might provide useful information about the degree of overstimulation of the $\beta$ cell and/or the occurrence of $\beta$-cell lysis in disease processes attacking this cell (I.P.Gray, K.Siddle, B. H. Frank and C. N. Hales, unpublished observations). We do not yet know the relevant figures for split and intact proinsulin in the various types and stages of diabetes.

It is chastening to reflect that after 25 years of developing methods and carrying out studies aimed at defining the insulin status of diabetic subjects, we are only now equipped with methods of adequate specificity and sensitivity to tackle the problem definitively.

\section{Other assay applications}

Considerable progress has been made in applying the immunoradiometric assay more generally since 1971 . Very recently the widespread commercial adoption of immunoradiometric assays as the method of choice for many polypeptides has come about because of the availability of monoclonal antibodies [22]. The inherent advantage of the two site method in kinetics, specificity, speed, sensitivity and precision are now technically easy to establish. A list of some polypeptides for which immunoradiometric assays have been established is given in Table 1. The ferritin assay, to which I referred as a new application in 1971, has become established as an integral part of the haematological diagnostic reper- 
toire, being an essential part of the assessment of iron status [23]. Perhaps this may be seen as a minor tradeoff for the haematologists donation to us of the measurement of glycosylated haemoglobin.

\section{The Purification of Cell Membranes}

At the time of the Minkowski Lecture, J.P. Luzio and I had just begun to explore the use of antibodies in the subcellular purification of membrane fragments. I suggested that this approach might be useful in further studies of cell membrane structure and function. It proved possible to devise a method which would isolate a hormone-sensitive rat fat-cell plasma membrane fraction within $30 \mathrm{~min}$ of homogenisation with a $25-40 \%$ recovery. The specific activity of the adenylate cyclase thus prepared was similar to that in fat-cell membranes prepared by much more laborious density-gradient methods $[24,25]$. The key to the successful use of immunological isolation proved to be to use an indirect method. Anti-immunoglobulin antibodies were coupled directly to cellulose and used to bind to antibodies directed against plasma membranes. The direct coupling of anti-membrane antibodies to the solid phase did not lead to a successful purification method. Ito and Palade subsequently found that the same approach could be used for the purification of Golgi membranes [26]. The great advantage of the approach is that it can separate membrane fractions of very similar or identical bouyant density. The immunological approach can separate membrane fractions whose sole difference may be orientation, for example "inside-out" vesicles derived from the plasma membrane [27].

Most recently the ability of the method to isolate membrane components of a specific cell type from a homogrenate of a tissue comprising a complex mixture of cells has been demonstrated [28]. My colleagues P.J. Richardson, K. Siddle and J.P.Luzio have succeeded in isolating metabolically active cholinergic nerve terminals from homogenates of rat brain.

\section{The secretion of insulin}

The majority of diabetic patients at some stage of the syndrome exhibit greater or lesser abnormalities of insulin secretion. The ability to measure insulin with ease and precision opened the way to basic studies of the mechanism and control of insulin secretion. In the early 1960s Douglas and Rubin, carrying out studies of neurologically controlled secretory processes, pointed out the close parallels between the ionic aspects of regulation of these processes with ionic aspects of the control of muscle contraction [29]. In those days it was not obvious that a secretory system controlled by a common metabolite, namely glucose, would utilise regulatory mech- anisms similar to those of muscle contraction. R.D.G. Milner and I set out to explore this possibility systematically [30-35]. Apart from the inherent interest of the question itself, we were also concerned to establish to what extent the known regulators of insulin secretion might act through a common pathway. Should any diabetic patients prove to have a selective block of glucose-stimulated insulin secretion, information about alternative pathways of stimulation would be of potential practical benefit. It was found that the ionic requirements of a number of stimuli were similar and we sug. gested that the $\beta$-cell membrane was polarised and that the membrane potential was potassium-dependent [31]. After defining the effects of extracellular cations and manipulations of the sodium pump on insulin secretion, we turned our attention to the intracellular localisation of cations. L. Herman spent a sabbatical year in Cambridge and we were able to explore the novel approach of combining cation precipitation with X-ray microprobe analysis [36]. We were able to locate calcium in the insulin secretory granule and along the plasma membrane and to show that the amount of calcium precipitated in these two locations was increased by the incubation of islets in the presence of high glucose concentrations. Subsequent electrophysiological and isotope studies in many other laboratories have greatly increased our understanding of the mechanism by which glucose stimulates insulin secretion. Probably the most generally held belief at the present time is that glucose metabolism leads, by a mechanism unknown, to a decrease in potassium permeability and hence to depolarisation. Subsequent ionic events, such as an increase in $\mathrm{Ca}^{2+}$ uptake, appear to be secondary to this depolarisation.

Our more recent approach to the study of the control of insulin secretion has been to explore the use of a tumour [37] and cell lines (C.A.Carrington, E. D. Rubery, and C.N.Hales, unpublished observations). The insulin-secreting tumour first described by Chick's group [38] appeared to offer a means of overcoming the severe limitation of the quantity of $\beta$-cell material available for study at the biochemical level. Shortly after the start of this work I was very fortunate to be joined by J.C.Hutton who has played a major role in the exploitation of this interesting preparation [39-42]. John has followed as his main interest the preparation and properties of the insulin secretory vesicle [43, 44]. I have most recently become interested in the role of phosphorylation in the regulation of membrane events.

I was very glad to have the opportunity to spend a sabbatical year in the laboratory of E.G. Krebs, Howard Hughes Institute of Medical Research, University of Washington, Seattle. Here, amongst many other procedures, I was able to study the techniques and learn the modern concepts of protein phosphorylation reactions from the founder of the subject. Another great benefit of being in Seattle was to be able to collaborate with D. L. Cook (Department of Biophysics and Physi- 
ology) and attached to D. Porte Jr.'s group in the Department of Medicine. D.C.Cook was pioneering the application of the patch-clamp technique to $\beta$ cells and we collaborated in a study aimed at the control of $\beta$-cell potassium permeability. The initial outcome of this work was the discovery of a novel potassium channel which is directly controlled by ATP [45]. Whether this channel provides the missing link connecting glucose metabolism to potassium permeability and $\beta$-cell membrane potential remains to be seen. This is certainly one of our major interests at the present time.

\section{Conclusions}

It seems that the methods described in 1971 have proved to be useful. Advances in other fields have greatly simplified their adoption. The availability of genetically engineered human proteins, together with monoclonal antibodies, suggests that the next few years will see a very large growth in the use of highly specific immunoradiometric assays for a wide variety of polypeptides, many of relevance to research in diabetes. Perhaps we may even finally describe what is really happening to plasma insulin and its related polypeptides during the different stages and in the different types of diabetes. Advances in our understanding of the basic mechanisms of the immune system, together with their role in diabetes, suggest that immunological methods and concepts will be at least as relevant to the subject in the next 25 years.

Acknowledgements. The work described above has been consistently supported by the British Diabetic Association, Medical Research Council and Wellcome Trust and I am most grateful for this. I also thank Allen \& Hanbury Research Ltd., the British Insulin Manufacturers, Eli Lilly \& Co. Ltd., Novo Laboratories Ltd. and Thomae for additional support. My colleagues in the Department have provided much helpful discussion and Drs. J.C. Hutton, J.P. Luzio and K. Siddle long term and very fruitful collaboration. Mrs. C. N. Lee Creswell with endless patience and care has provided skilled secretarial and managerial assistance which is greatly appreciated.

\section{References}

1. Hales CN (1972) Immunological techniques in diabetes research. Diabetologia 8: 229-235

2. Randle PJ, Garland PB, Hales CN, Newsholme EA (1963) The glucose fatty-acid cycle: its role in insulin sensitivity and the metabolic disturbances of diabetes mellitus. Lancet 1: 785-789

3. Young FG (1937) Permanent experimental diabetes produced by pituitary (anterior lobe) injections. Lancet 2: 372-374

4. Randle PJ, Hales CN (1963) Effects of low-carbohydrate diet and diabetes mellitus on plasma concentrations of glucose, non-esterified fatty acid, and insulin drug oral glucose-tolerance tests. Lancet 1: $790-794$

5. Hales CN (1967) Plasma levels of glucose, non-esterified fatty acid, glycerol, and insulin four years before the onset of diabetic ketosis. Lancet 2: 389-390
6. Strauss WT, Hales CN (1974) Plasma insulin in minor abnormalities of glucose tolerance: a five year follow-up. Diabetologia 10: $237-243$

7. Milner RDG, Hales CN (1969) The interaction of various inhibitors and stimuli of insulin release studied with rabbit pancreas in vitro. Biochem J 113: 473-479

8. Greenwood RH, Mahler RF, Hales CN (1976) Improvement in insulin secretion in diabetes after diazoxide. Lancet 1: 444-447

9. Miles LEM, Hales CN (1968) The preparation and properties of ${ }^{125}$ I-labelled antibodies to insulin. Biochem J 108: 611-618

10. Miles LEM, Hales CN (1968) Labelled antibodies and immunological assay systems. Nature 219: 186-189

11. Addison GM, Hales CN (1971) Two site assay of human growth hormone. Horm Metab Res 3: 59-60

12. Beck $P$, Hales CN (1975) Immunoassay of serum polypeptide hormones by using ${ }^{125}$ I-labelled anti-(immunoglobulin $G$ ) antibodies. Biochem J 145: 607-616

13. Rainbow SJ, Woodhead JS, Yue DK, Luzio SD, Hales CN (1979) Measurement of human proinsulin by an indirect two-site immunoradiometric assay. Diabetologia 17:229-234

14. Yue DK, Gibby OM, Luzio SD, Yanaihara N, Hales CN (1979) Indirect two-site immunoradiometric assay of rat and mouse proinsulin. Diabetologia 17: 235-242

15. Sopwith AM, Hales CN (1980) Micromodification of an immunoradiometric assay for proinsulin. Ann Clin Biochem 17: 185-187

16. Greenwood RH, Rainbow S, Luzio S, Mahler RF, Hales CN (1978) Is hyperproinsulinaemia in diabetes due to the release of immature beta granules? Diabetologia 15:235 (Abstract)

17. Campbell AK, Daw RA, Hallett MB, Luzio JP (1981) Direct measurement of the increase in intracellular free calcium ion concentration in response to the action of complement. Biochem J 194: $551-560$

18. Campbell AK, Luzio JP (1981) Intracellular free calcium as a pathogen in cell damage initiated by the immune system. Experientia 37: 1110-1112

19. Frank BH, Pettee JM, Zimmerman RE, Burck PJ (1981) The production of human proinsulin and its transformation to human insulin and C-peptide. In: Rich DH, Gross E (eds) Peptides: synthesis-structure-function. Proceedings of the 7th American Peptide Symposium. Pierce Chemical Company, pp 729-738

20. Kohler G, Milstein C (1975) Continuous cultures of fused cells secreting antibody of predefined specificity. Nature 256: 495-497

21. Gray IP, Siddle K, Docherty K, Frank BH, Hales CN (1984) Proinsulin in human serum: problems in measurement and interpretation. Clin Endocrinol 21: 43-47

22. Siddle K (1985) Monoclonal antibodies in clinical biochemistry. In: Prince CP, Alberti KGMM (eds) Recent advances in clinical biochemistry. Churchill Livingstone, Edinburgh, pp 63-102

23. Worwood M (1982) Ferritin in human tissues and serum. Clin Haematol 11: 275-307

24. Luzio JP, Newby AC, Hales CN (1974) Immunological isolation of rat fat-cell plasma membranes. Biochem Soc Trans 2: 1385-1386

25. Luzio JP, Newby AC, Hales CN (1976) A rapid immunological procedure for the isolation of hormonally sensitive rat fat-cell plasma membrane. Biochem J 154: 11-21

26. Ito A, Palade GE (1978) Presence of NADPH-cytochrome P-450 reductase in rat Golgi membranes. J Cell Biol 79:590-597

27. Luzio JP, Stanley KK (1983) The isolation of endosome-derived vesicles from rat hepatocytes. Biochem J 216: 27-36

28. Richardson PJ, Siddle K, Luzio JP (1984) Immunoaffinity purification of intact, metabolically active, cholinergic nerve terminals from mammalian brain. Biochem J 219: 647-654

29. Douglas WW, Rubin RP (1961) The role of calcium in the secretory response of the adrenal medulla to acetylcholine. J Physiol 159: $40-57$

30. Milner RDG, Hales CN (1967) The role of calcium and magnesium in insulin secretion from rabbit pancreas studied in vitro. Diabetologia 3: 47-49 
31. Milner RDG, Hales CN (1967) The stimulation by potassium of insulin secretion from rabbit pancreas in vitro. Biochem J 105:28P

32. Milner RDG, Hales CN (1967) The sodium pump and insulin secretion. Biochim Biophys Acta 135: 375-377

33. Milner RDG, Hales CN (1968) Cations and the secretion of insulin. Biochim Biophys Acta 150: 165-167

34. Hales CN, Milner RDG (1968) The role of sodium and potassium in insulin secretion from rabbit pancreas. J Physiol 194: 725-743

35. Hales CN, Milner RDG (1968) Cations and the secretion of insulin from rabbit pancreas in vitro. J Physiol 199: 177-187

36. Herman L, Sato T, Hales CN (1973) The electron microscopic localisation of cations to pancreatic islets of Langerhans and their possible role in insulin secretion. J Ultrastruct Res 42: 298-311

37. Sopwith AM, Hutton JC, Naber SP, Chick WL, Hales CN (1981) Insulin secretion by a transplantable rat islet cell tumour. Diabetologia 21: 224-229

38. Chick WL, Warren S, Chute RN, Like AA, Lauris V, Kitchen KC (1977) Proc Natl Acad Sci USA 74: 628-632

39. Hutton JC, Penn EJ, Jackson P, Hales CN (1981) Isolation and characterisation of calmodulin from an insulin-secreting tumour. Biochem J 193: 875-885

40. Penn EJ, Brocklehurst KW, Sopwith AM, Hales CN, Hutton JC
(1982) $\mathrm{Ca}^{2+}$-calmodulin dependent myosin light-chain phosphorylating activity in insulin-secreting tissues. FEBS Lett 139:4-8

41. Tooke NE, Hales CN, Hutton JC (1984) $\mathrm{Ca}^{2+}$-sensitive phosphatidyl-inositol 4-phosphate metabolism in a rat $\beta$-cell tumour. Biochem J 219: 471-480

42. Sopwith AM, Hales CN, Hutton JC (1984) Pancreatic B-cells secrete a range of novel peptides besides insulin. Biochem Biophys Acta 803:342-345

43. Hutton JC, Penn EJ, Peshavaria M (1982) Isolation and characterisation of insulin secretory granules from a rat islet cell tumour. Diabetologia 23: 365-373

44. Hutton JC (1984) Secretory granules. Experientia 40: 1091-1098

45. Cook DL, Hales CN (1984) Intracellular ATP directly blocks $\mathrm{K}^{+}$ channels in pancreatic B-cells. Nature 311: 271-273

Professor C. N. Hales

Department of Clinical Biochemistry

Addenbrooke's Hospital

Hills Road

Cambridge CB 2 2QR

UK 